\title{
Running GAGs: myxoid matrix in tumor pathology revisited
}

\author{
What's in it for the pathologist?
}

\author{
Stefan M. Willems • Malgorzata Wiweger • \\ J. Frans Graadt van Roggen • \\ Pancras C. W. Hogendoorn
}

Received: 27 June 2009 / Accepted: 3 August 2009 /Published online: 25 August 2009

(C) The Author(s) 2009. This article is published with open access at Springerlink.com

\begin{abstract}
Ever since Virchow introduced the entity myxoma, abundant myxoid extracellular matrix (ECM) has been recognized in various reactive and neoplastic lesions. Nowadays, the term "myxoid" is commonly used in daily pathological practice. But what do today's pathologists mean by it, and what does the myxoid ECM tell the pathologist? What is known about the exact composition and function of the myxoid ECM 150 years after Virchow? Here, we give an overview of the composition and constituents of the myxoid ECM as known so far and demonstrate the heterogeneity of the myxoid ECM among different tumors. We discuss the possible role of the predominant constituents of the myxoid ECM and attempt to relate them to differences in clinical behavior. Finally, we will speculate on the potential relevance of this knowledge in daily pathological practice.
\end{abstract}

Keywords Extracellular matrix · Glycosaminoglycans ·

Proteoglycan · Collagen · Myxofibrosarcoma .

Intramuscular myxoma

\section{Historical perspective}

In his 1858 masterpiece Cellularpathologie, Rudolph Virchow introduced the term "myxoma" to describe a soft tissue tumor, histologically resembling the structure of the

S. M. Willems • M. Wiweger • P. C. W. Hogendoorn $(\bowtie)$ Department of Pathology, Leiden University Medical Center, L1Q, P.O. Box 9600, 2300 RC Leiden, The Netherlands e-mail: P.C.W.Hogendoorn@lumc.nl

J. F. G. van Roggen

Department of Pathology, Diaconessenhuis Hospital, Leiden, The Netherlands umbilical cord (Figs. 1 and 2) [1]. This description of myxoma was adopted in the seventh edition of the Medical Lexicon by Robley Dunglison who remarkably added that "[myxoma] was for the first time described in 1838 by Johannes Müller as Collonema" [2]. Müller used the term collonema $(\kappa \circ \lambda \lambda \alpha=$ glue) for "peculiar gelatinous tumours, consisting of a remarkably soft gelatiniform tissue, which trembles on being touched" [3]. Though this description is applicable to most myxoid tumors, it holds also for many nonmyxoid tumors and it is not particularly clear which tumor type Müller had in mind. Today, it has been generally accepted that it was indeed Virchow who introduced myxoma as an entity. The introduction of this new histological concept of tumors containing myxoid ( $\mu v \dot{\xi} \alpha \alpha=$ "mucus" and $\varepsilon\llcorner\delta o \varsigma=$ "resemblance") areas soon led to the recognition of new entities, such as myxadenoma, myxochondroma, myxofibroma, and myxoneuroma [2]. The term myxosarcoma, introduced in 1802 by Bryant [4], became reserved for malignant tumors and defined as "a mucous transformation of round-celled sarcoma, malignant, and of large volume, usually attacking the omentum and the skin" [2]. Nowadays, myxoid changes/areas are recognized in both benign and malignant neoplasms (primarily classified as mesenchymal or epithelial) as well as non-neoplastic (reactive) lesions (Fig. 3).

In his first description, Virchow had already recognized the recurrent nature of some myxomatous tumors [1] and it became clear that it was difficult to predict the exact clinical behavior of these different tumors based on their myxoid morphology alone. Subsequently, the terms myxoma and myxosarcoma were used interchangeably till Arthur Stout recognized this as unwise [5] because "myxomas do not metastasize and there is no way to anticipate differences in their growth energy from their histopathology." Later studies confirmed the distinction between both entities on 


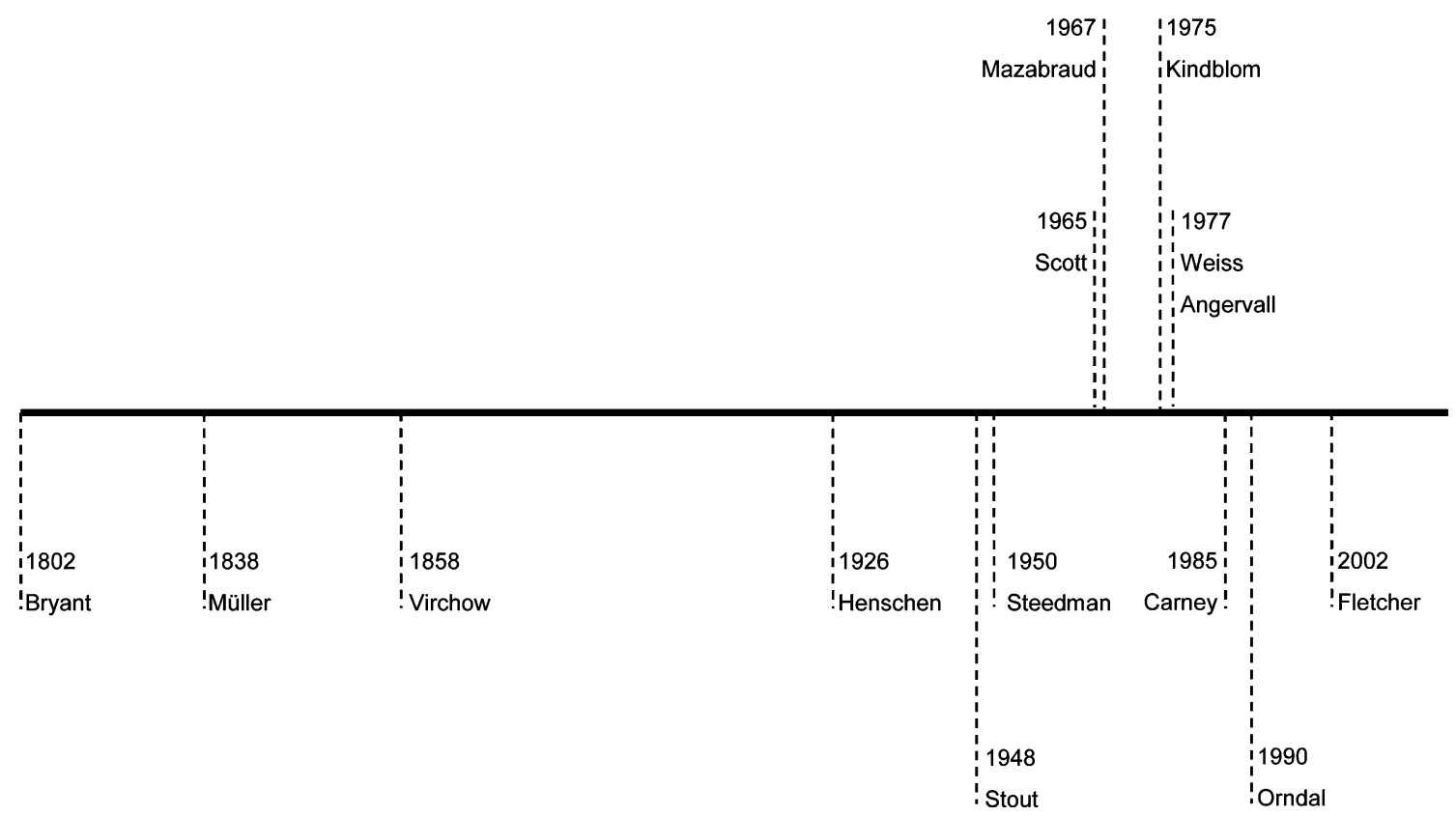

Fig. 1 Timetable with key events in studies on myxoid tumors of soft tissue. Though Müller already mentioned tumors with a macroscopically gelatinous appearance in 1838 [3], it was in 1858 when Virchow introduced the term myxoma to describe tumors which morphologically resembled the jelly structure of the umbilical cord [1]. Ever since, the term myxosarcoma, introduced by Bryant in 1802 was reserved for the malignant counterparts [4]. Because of their morphologically overlapping features, both terms were used interchangeably, which was mentioned by Stout in 1948 as unwise, warranting for macroscopical and microscopical criteria for the reliable differential diagnosis between the two entities [5]. The relationship between myxomas and fibrous dysplasia was first described in 1926 by Henschen [90], though it was Mazabraud who proposed it as a syndrome in 1967 [91]. The association of cardiac/ cutaneous myxomas, hyperpigmentation of the skin, and endocrine overactivity was only recognized in 1985 by Carney [43]. Progress in the study of the myxoid ECM was made by the invention of the alcian blue staining in 1950 by Steedman [9], and Scott who developed the

the basis of macroscopical and microscopical features (necrosis, nuclear atypia, and mitotic figures; Fig. 2) [6]. Today, myxoid tumors of soft tissue are classified according to the World Health Organization (WHO) formulation based on clinicopathological criteria and specific molecular/cytogenetic aberrations (Table 1) [7,8]. So what is left of the term "myxoid" 150 years after Virchow? What do today's pathologists mean by it, and what does the myxoid extracellular matrix (ECM) tell the pathologist? What is the exact composition of this myxoid ECM and does it have a function? Here, we give an overview of the composition and constituents of the myxoid ECM as known so far and demonstrate the heterogeneity of the myxoid ECM among different tumors. We discuss the possible role of the predominant constituents of the myxoid ECM and attempt to relate them to differences in clinical behavior. Finally, we
CEC method to distinguish the different GAGs in 1965 [10]. Based upon this technique, Kindblom showed in 1975 that different bone and soft tissue tumors (including myxoid ones) contained different GAGs [11]. From the late 1980s, it became clear that the ECM is a key player in tumor development and tumor progression, sustained by an exponentially growing number of publications [40]. As myxoid areas were now being recognized as an intrinsic part of a subset of tumors, Weiss and Angervall simultaneously described the myxoid variant of malignant fibrous histiocytoma/myxofibrosarcoma as a distinct entity [92, 93]. Parallel to morphological classification, an increasing number of myxoid tumors showed specific molecular genetics aberrations, such as (activating) mutations and translocations. The concept of malignant progression in myxoid tumors of soft tissue (i.e., myxoid liposarcoma) due to chromosomal instability and subsequent secondary genetic events was described in 1990 by Orndal et al. [94]. Nowadays, classification of myxoid tumors of soft tissues is based upon clinicopathological and molecular/cytogenetic aberrations as published in the 2002 WHO classification [7]

will speculate on the potential relevance of this knowledge in daily pathological practice.

\section{Composition of the myxoid extracellular matrix}

Glycosaminoglycans and proteoglycans

Substantial progress in the study of the myxoid ECM was made after the introduction of alcian blue staining in 1950 [9]. John Scott was one of the pioneers who used this histochemical stain to distinguish between the different glycosaminoglycans (GAGs) in tissue sections [10]. Kindblom et al. showed that the myxoid ECM of various (non)neoplastic tissues, i.e., Wharton's jelly and myxoid tumors of soft tissue, contained large amounts of GAGs 

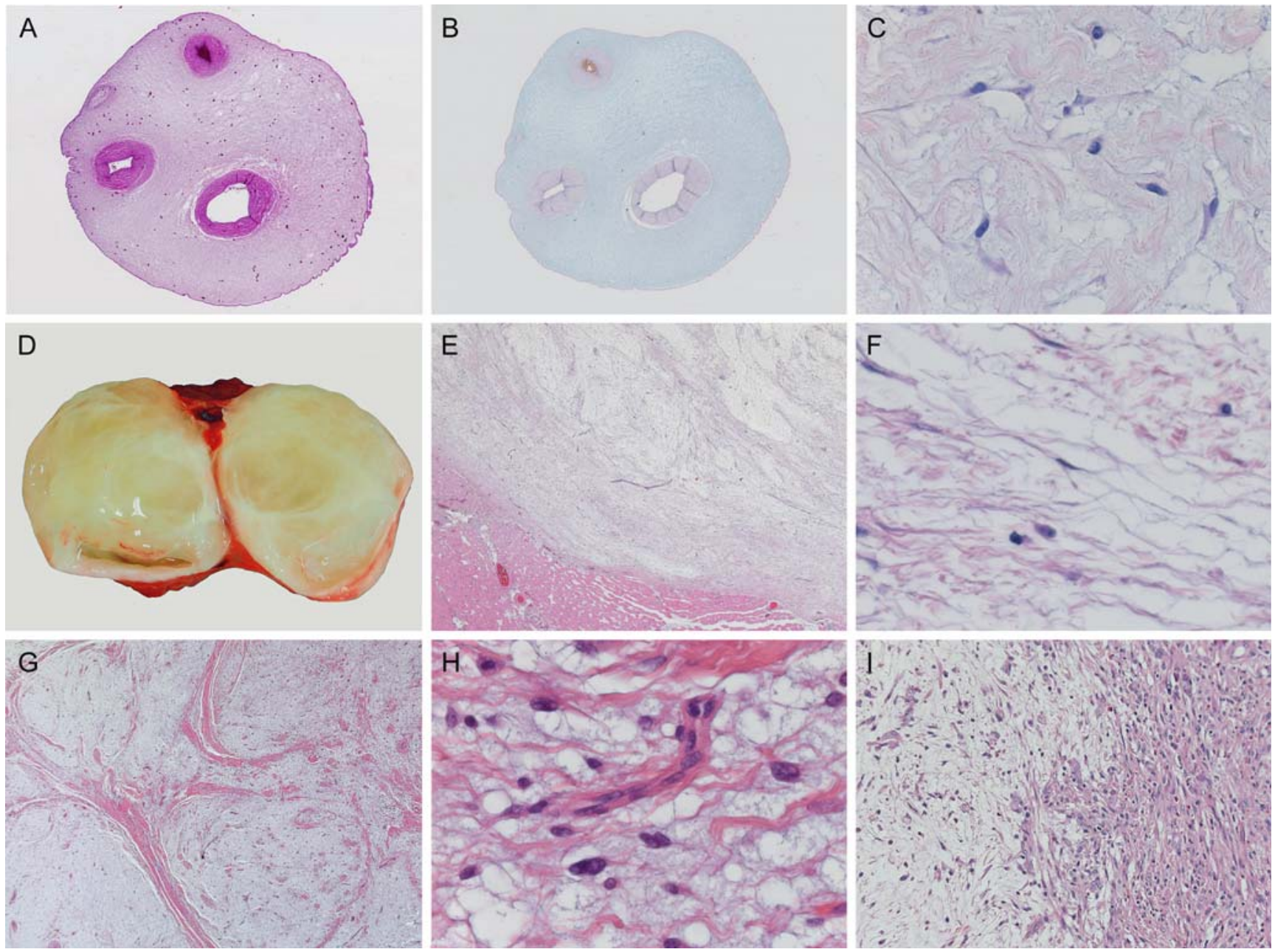

Fig. 2 Characteristic macroscopy and histomorphology of the myxoid ECM. Rudolph Virchow introduced the term myxoma for those tumors morphologically resembling Wharton's jelly of the umbilical cord (a), which contains large amounts of GAGs as detected by alcian blue (b). High-power image of Wharton's jelly showing abundant myxoid ECM containing fibrillary collagens, interspersed between myofibroblast-like stroma cells (c). Intramuscular myxoma characteristically has a gelatinous appearance on cut surface (d) and is well circumscribed towards its peripheral tissue (e). On higher magnification, it shows the same abundant myxoid ECM as the umbilical cord

(Figs. 1 and 2) [11]. GAGs are large macromolecules abundantly present in pericellular and extracellular matrices and consist of unbranched polysaccharide chains of disaccharides which are often sulfated. There are six different types of GAGs: hyaluronic acid (HA), keratin sulfate, chondroitin sulfate, dermatan sulfate, heparan sulfate, and heparin [12]. GAGs form proteoglycans (PGs) once covalently attached to specific core proteins. Core proteins of PGs are synthesized in the endoplasmic reticulum and post-translationally modified as they pass through the Golgi apparatus where hexuronic acid and hexosamine groups are attached. The exception is HA, which is synthesized directly under the cytoplasmic membrane by the hyaluronic (c) and no significant atypia of the sparse tumor cells (f). Histological criteria are still a hallmark of diagnosis, showing characteristic lobulated, hypocellular morphology of grade I myxofibrosarcoma at low magnification (g).Curvilinear blood vessels are often seen in grade I myxofibrosarcoma (but are not diagnostic), whereas tumor cells show vesicular, slightly atypical nuclei compared to intramuscular myxoma (h). Another hallmark of myxofibrosarcoma is areas with abrupt transition of grade (i) which was already mentioned by Mentzel et al. [95]

acid synthetases 1, 2, and 3 [12]. The most common classification of the different PGs is based upon the properties of the core protein. The three main PG families present in the ECM are lecticans, small leucine-rich proteoglycans (SLRPs), and other ECM PG [13]. Lecticans always contain both a hyaluronan-binding domain and a Ctype lectin domain. The lectican family includes: aggrecan, versican, neurocan, and brevican that can be found at different locations (Table 3) [12]. SLRPs can be found extracellularly and intracellularly and at the cell surface. They contain nine to 12 tandem repeats of leucine-rich motifs which involve their collagen-binding domains. The SLRP family includes decorin, biglycan, asporin, ECM 


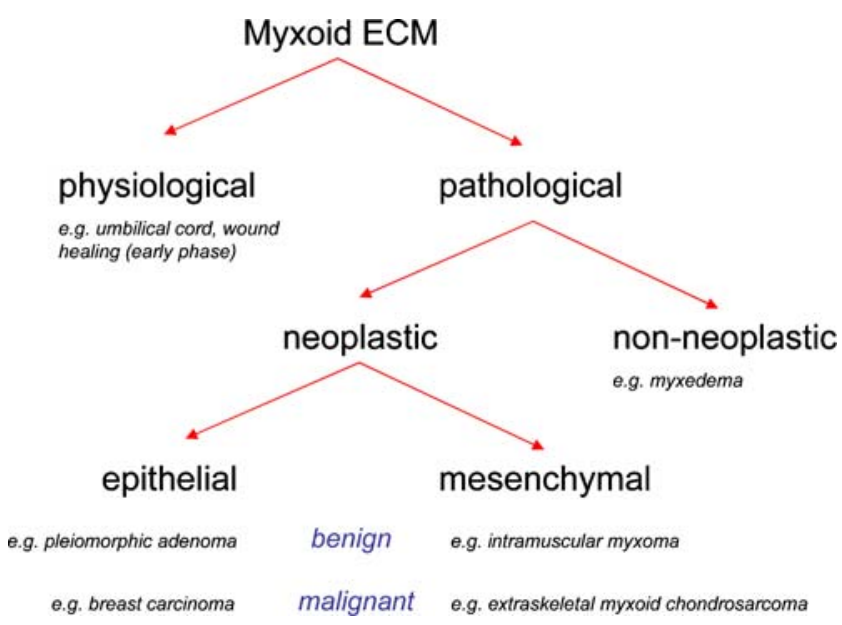

Fig. 3 Myxoid ECM is a ubiquitously histological feature in physiological and pathological conditions. Myxoid ECM is a morphological feature in physiological and pathological conditions, such as in myxedema due to increased production of HA. Myxoid areas/changes are also commonly present in tumors (both of epithelial and mesenchymal origin). In epithelial tumors, myxoid changes are often a secondary phenomenon, whereas in mesenchymal tumors, they are more frequently an intrinsic part of the tumor entity. This group of so-called myxoid tumors of soft tissues contains an increasing number of entities (e.g., myxofibrosarcoma, formerly called myxoid variant of malignant fibrous histiocytoma), sometimes sustained by specific distinct molecular/cytogenetic aberrations (e.g., myxoid liposarcoma)

protein 2, keratocan, proline/arginine-rich and leucine-rich repeat proteins, osteoadherin, lumican, fibromodulin, opticin, epiphycan, osteoglycin, podocan, chondroadherin, and nyctalopin [14]. ECM PGs do not show significant homology in the content of their core proteins. Perlecan, agrin, and collagen types XV and XVIII belong in this family [14]. Various GAGs and PGs have been identified in the myxoid ECM (Table 2): HA is the most common; none of them are specific for one particular lesion.

\section{Collagens}

One of the first papers addressing myxoma and its malignant counterpart ("myxosarcoma") mentioned the presence of fibrillary collagens as a hallmark for differential diagnosis [6]. Though this criterion did not last long, collagens ( $\kappa \circ \lambda \lambda \alpha=$ glue; $\gamma \eta \nu \varepsilon=$ that which produces) are a main component of the myxoid ECM. They are characterized by their regular, triple-stranded helix of socalled alpha-chains forming cord-like strands of $300 \mathrm{~nm}$ in length and $1.5 \mathrm{~nm}$ in diameter. A separate group of collagens is formed by the fibril-associated collagens with interrupted triple helices (FACIT) and includes collagen types XII and XIV. These collagens have several triple helical domains (collagen type domains [Col]) separated by nontriple helical domains (NC). All collagens contain large amounts of proline and glycine as well as hydroxyproline and hydroxylysine which are formed by post-translational modification. Based on their biochemical differences, more than 30 different types of collagens are recognized [15]. The most common types are I, II, III, and IV, which account for $90 \%$ of all collagens in humans. Except for collagen II, which is predominantly present in cartilage, collagen types I, III, and IV as well as VI, XII, and XIV may be found in the myxoid ECM (Table 2).

\section{Other ECM molecules}

Other structural molecules identified in the myxoid ECM are fibronectin and tenascin $\mathrm{C}$ (Table 2). Fibronectin is a fibril-forming glycoprotein existing in a dimeric or multimeric form. Each monomer contains several binding sites for fibrin, heparin, DNA, and cells. Fibronectin molecules consist of different repeats (types I, II, and III) and three different sites that can be alternatively spliced (EDA, EDB, and $\mathrm{V}$ ). The dimeric, soluble form is produced by hepatocytes and lacks the alternative EDA and EDB variants. The multimeric form is extensively present in granulation tissue, basement membrane, and on cell surfaces and contains variable proportions of the EDA and EDB domains [16]. Until now, fibronectin has only been found in myxoid liposarcoma but might also be present in the ECM of other myxoid lesions (Table 2).

Tenascin $\mathrm{C}$ is a highly conserved glycoprotein of the ECM consisting of $300 \mathrm{kDa}$ monomers, characteristically assembled in $1,800 \mathrm{kDa}$ hexamers [17, 18]. It consists of several functionally independent domains of which the number is dramatically increased by alternative splicing. The N-terminal contains the cysteine-rich assembly domain, followed by EGF-like repeats, eight constant and up to nine alternatively spliced fibronectin type III repeats and a C-terminal fibrinogen-like globular domain [18]. Till today, its presence has only been shown in myxoid areas of epithelial but not (yet) in mesenchymal tumors (Table 2).

\section{Functional role of the different constituents in the myxoid extracellular matrix}

\section{Glycosaminoglycans}

GAGs have both biophysical and biochemical functions and play important roles in physiologic and neoplastic processes (Table 3) [19]. Due to their high content of sulfate and carboxyl groups, complex patterns of sulfation and uronic acid epimerizations, GAG chains confer upon PGs the diverse capacities to function as ideal physiological barriers, reservoirs for signaling proteins, and binding partners for structural macromolecules [13]. We have 
Table 1 Myxoid tumors of soft tissue: overview of clinicopathological and genetic features

\begin{tabular}{|c|c|c|c|c|c|}
\hline Myxoid tumors of soft tissue & Age & Sex & Predilection site & Molecular/cytogenetic aberrations & References \\
\hline \multicolumn{6}{|l|}{ Benign } \\
\hline $\begin{array}{l}\text { Intramuscular myxoma (including } \\
\text { its cellular variant) }\end{array}$ & Adults & $\mathrm{F}>\mathrm{M}$ & $\begin{array}{l}\text { Thigh, shoulder, buttocks, } \\
\text { and rarely upper arm }\end{array}$ & GNAS1 mutations & [34] \\
\hline Myxoid neurothekeoma & $\begin{array}{l}\text { Young } \\
\text { adults }\end{array}$ & $\mathrm{F}>\mathrm{M}$ & Head, neck, and shoulders & Loss of $22 q$ & {$[8]$} \\
\hline Myxoid lipoma (myxolipoma) & Any age & $\mathrm{F}=\mathrm{M}$ & Head and neck & Rearrangement of $13 \mathrm{q}$ and/or $16 \mathrm{q}$ & {$[8]$} \\
\hline Myxoid chondroma & Adults & $\mathrm{M}>\mathrm{F}$ & Hands and feet & $\begin{array}{l}\text { Extra copies of chromosome } 5 \text { or } \\
12 q 13-15 \text { rearrangement }\end{array}$ & [8] \\
\hline Myxoid neurofibroma & Any age & $\mathrm{M}=\mathrm{F}$ & All over the body & NF1 mutations & {$[8]$} \\
\hline Myxoid dermatofibroma & $\begin{array}{l}\text { Young } \\
\text { adults }\end{array}$ & $\mathrm{F}>\mathrm{M}$ & Lower extremities & Unknown & {$[42]$} \\
\hline Cardiac myxoma & Adults & $\mathrm{F}>\mathrm{M}$ & Atria (predominantly left) & $\begin{array}{l}\text { PRKAR } 1 \alpha \text { mutations in Carney } \\
\text { complex }\end{array}$ & [43] \\
\hline Ossifying fibromyxoid tumor & Elderly & $\mathrm{M}>\mathrm{F}$ & Extremities and trunk & Nonspecific cytogenetic aberrations & [8] \\
\hline Cutaneous myxoid cyst & Any age & $\mathrm{F}>\mathrm{M}$ & $\begin{array}{l}\text { Distal and dorsal portions } \\
\text { of fingers (and toes) }\end{array}$ & Unknown & {$[8]$} \\
\hline $\begin{array}{l}\text { Cutaneous myxoma (superficial } \\
\text { angiomyxoma) }\end{array}$ & Adults & $\mathrm{M}>\mathrm{F}$ & $\begin{array}{l}\text { Trunk, lower extremities, } \\
\text { head, and neck }\end{array}$ & $\begin{array}{l}\text { PRKAR } 1 \alpha \text { mutations in Carney } \\
\text { complex }\end{array}$ & [43] \\
\hline Myxoid nodular fasciitis & $\begin{array}{l}\text { Young } \\
\text { adults }\end{array}$ & $\mathrm{M}=\mathrm{F}$ & $\begin{array}{l}\text { Head, neck, and } \\
\text { extremities }\end{array}$ & Nonspecific cytogenetic aberrations & {$[8,44]$} \\
\hline \multicolumn{6}{|l|}{ Locally aggressive } \\
\hline Odontogenic myxoma & $\begin{array}{l}\text { Young } \\
\text { adults }\end{array}$ & $\mathrm{F}>\mathrm{M}$ & Mandible and maxilla & $\begin{array}{l}\text { PRKAR } 1 \alpha \text { mutations in rare cases } \\
\text { (not Carney complex) }\end{array}$ & {$[45]$} \\
\hline $\begin{array}{l}\text { Myxoinflammatory fibroblastic } \\
\text { sarcoma }\end{array}$ & Adults & $\mathrm{M}=\mathrm{F}$ & Feet, lower leg & $\begin{array}{l}\mathrm{t}(1 ; 10)(\mathrm{p} 22 ; \mathrm{q} 24) \text { and amplification of } \\
\text { chromosome } 3\end{array}$ & {$[46]$} \\
\hline Aggressive angiomyxoma & Adults & $\mathrm{F}>>\mathrm{M}$ & Inguinal region & Rearrangement of $12 \mathrm{q} 13-15$ & [8] \\
\hline \multicolumn{6}{|l|}{ Malignant } \\
\hline Myxofibrosarcoma & Elderly & $\mathrm{M}=\mathrm{F}$ & Extremities, thigh & Nonspecific cytogenetic aberrations & {$[47,48]$} \\
\hline $\begin{array}{l}\text { Extraskeletal myxoid } \\
\text { chondrosarcoma }\end{array}$ & Adults & $\mathrm{M}>\mathrm{F}$ & Extremities and limb & $\begin{array}{l}\mathrm{t}(9 ; 22)(\mathrm{q} 22 ; \mathrm{q} 12), \mathrm{t}(9 ; 17)(\mathrm{q} 22 ; \mathrm{q} 11) \text { or } \mathrm{t} \\
(9 ; 15)(\mathrm{q} 22 ; \mathrm{q} 21)\end{array}$ & [49] \\
\hline Low-grade fibromyxoid sarcoma & $\begin{array}{l}\text { Young } \\
\text { adults }\end{array}$ & $\mathrm{M}>\mathrm{F}$ & $\begin{array}{l}\text { Proximal extremities } \\
\text { and trunk }\end{array}$ & $\mathrm{t}(7,16)(\mathrm{q} 33 ; \mathrm{p} 11)$ & {$[50]$} \\
\hline Myxoid liposarcoma & Elderly & $\mathrm{M}>\mathrm{F}$ & $\begin{array}{l}\text { Lower extremities and } \\
\text { thigh }\end{array}$ & $\mathrm{t}(12 ; 16)(\mathrm{q} 13 ; \mathrm{p} 11)$ or $\mathrm{t}(12 ; 22)(\mathrm{q} 13 ; \mathrm{q} 12)$ & [51] \\
\hline $\begin{array}{l}\text { Myxoid leiomyosarcoma of soft } \\
\text { tissue }\end{array}$ & Adults & $\mathrm{F}>>\mathrm{M}$ & $\begin{array}{l}\text { Limbs, female genitalia, } \\
\text { head, and neck }\end{array}$ & Nonspecific cytogenetic aberrations & {$[52]$} \\
\hline $\begin{array}{l}\text { Myxoid malignant peripheral } \\
\text { nerve sheath tumor }\end{array}$ & Adults & $\mathrm{F}=\mathrm{M}$ & Extremities, trunk & $\begin{array}{l}\text { NF1 and TP53 mutations, P16 } \\
\text { deletions }\end{array}$ & {$[8,53]$} \\
\hline Myxoid dermatofibrosarcoma & Adults & $\mathrm{M}=\mathrm{F}$ & $\begin{array}{l}\text { Trunk, groin, and } \\
\text { extremities }\end{array}$ & $\mathrm{t}(17 ; 22)(\mathrm{q} 22 ; \mathrm{q} 13)$ & [54] \\
\hline
\end{tabular}

shown that the myxoid ECM in soft tissue tumors is heterogeneous in composition and that the relative amount of each GAG is tumor-type- and tumor-grade-dependent [20]. Because of their negative charge, all GAGs, especially $\mathrm{HA}$, are able to trap water molecules. Interestingly, HA is the common denominator in the myxoid ECM (Table 2). This suggests that $\mathrm{HA}$ is the major contributor to the edematous appearance of the myxoid ECM. As a result of the biophysical properties of GAGs (their high viscosity and low compressibility), they are ideal for tissue lubrication. On the other hand, their rigidity is responsible for the structural integrity of tissues facilitating diffusion of metabolites and cell migration [21]. The biochemical properties of GAGs are mediated by specific binding to other macromolecules. GAGs can bind to secreted proteases and antiproteases, growth factors, structural ECM proteins, and proteins expressed on (tumor) cells [22]. Chondroitin sulfate modulates cell fate as it appears to prevent apoptosis and is involved in cell proliferation. Since chondroitin sulfate is much more abundant in the ECM of extraskeletal myxoid chondrosarcoma compared to intramuscular myxoma and myxofibrosarcoma, it might, therefore, play a role in the more malignant behavior of this tumor [20]. Large multidomain ECM molecules such as collagen types I, III, V, and XIV and fibronectin contain at least one GAG binding site. This allows them to bind to heparan and chondroitin sulfates on cells or in the ECM, contributing to proper ECM formation. 
Table 2 The composition of the myxoid ECM is heterogeneous but not lesion-specific

Proteoglycans

\section{Collagens} (types)

\begin{tabular}{|c|c|c|c|c|}
\hline \multicolumn{5}{|l|}{ Non-neoplastic myxoid lesions } \\
\hline Follicular mucinosis & HA & & & {$[55]$} \\
\hline Myxedema & HA & I (III) & & {$[56,57]$} \\
\hline Stenotic arteries & $\begin{array}{l}\text { Versican, biglycan, perlecan, } \\
\text { HA }\end{array}$ & I & TBFbeta1 & {$[58,59]$} \\
\hline Pseudoaneurysm & Versican & & & {$[60]$} \\
\hline Endocardiosis & HA & & & {$[61]$} \\
\hline Valvular degeneration of the heart & & I, III & & {$[62]$} \\
\hline \multicolumn{5}{|l|}{ Myxoid tumors of soft tissue } \\
\hline Intramuscular myxoma & $\mathrm{KS}, \mathrm{HA}, \mathrm{C} 4 \mathrm{~S}, \mathrm{C} 6 \mathrm{~S}$ & I, VI & Albumin, IgGs & {$[20,34]$} \\
\hline Myxofibrosarcoma & $\mathrm{KS}, \mathrm{HA}, \mathrm{C} 4 \mathrm{~S}, \mathrm{C} 6 \mathrm{~S}$ & $\begin{array}{l}\text { I, VI, XII, } \\
\text { XIV }\end{array}$ & $\begin{array}{l}\text { Thrombospondin } \\
\text { Albumin, IgGs }\end{array}$ & {$[8,20,34]$} \\
\hline $\begin{array}{l}\text { Extraskeletal myxoid } \\
\text { chondrosarcoma }\end{array}$ & C4S, C6S, HA (aggrecan) & $\begin{array}{l}\text { I, III, VI (II, } \\
\text { IV) }\end{array}$ & Albumin, IgGs & {$[20,63]$} \\
\hline Odontogenic myxoma & $\begin{array}{l}\mathrm{C} 4 \mathrm{~S}, \mathrm{C} 6 \mathrm{~S}, \mathrm{DS}, \mathrm{KS}, \mathrm{HS} \text {, aggrecan, versican, } \\
\text { biglycan, decorin }\end{array}$ & & & {$[64]$} \\
\hline Low-grade fibromyxoid sarcoma & HA & & & {$[65]$} \\
\hline Myxoid neurothekeoma & HA & & & {$[66]$} \\
\hline Myxoid lipoma (myxolipoma) & HA & & & {$[67]$} \\
\hline Myxoid liposarcoma & HA & & FN & {$[68]$} \\
\hline Myxoid chondroma & $\mathrm{HA}, \mathrm{KS}$ & & & {$[69]$} \\
\hline Myxoid neurofibroma & $\mathrm{HA}, \mathrm{C} 4 \mathrm{~S}, \mathrm{C} 6 \mathrm{~S}$ & & & {$[69]$} \\
\hline Chondromyxoid fibroma & Aggrecan & I, III, VI & & {$[70]$} \\
\hline Myxoid dermatofibroma & HA & & & {$[71]$} \\
\hline Myxoid leiomyosarcoma & HA & & & {$[72]$} \\
\hline Cardiac myxoma & C4S, C6S, (HA) & & & {$[73]$} \\
\hline Ossifying fibromyxoid tumor & & IV (II) & & {$[74,75]$} \\
\hline $\begin{array}{l}\text { Myxoinflammatory fibroblastic } \\
\text { sarcoma }\end{array}$ & & & $\mathrm{A} 1 \mathrm{AT}, \mathrm{A} 1 \mathrm{ACT}$ & {$[76]$} \\
\hline Cutaneous myxoid cyst & HA & & & {$[77]$} \\
\hline Aggressive angiomyxoma & HA & & & {$[78]$} \\
\hline $\begin{array}{l}\text { Cutaneous myxoma (superficial } \\
\text { angiomyxoma) }\end{array}$ & HA & & & {$[79]$} \\
\hline \multicolumn{5}{|l|}{ Myxoid areas in epithelial tumors } \\
\hline Breast carcinoma & Aggrecan, versican, HA & I, II, IV & & {$[80]$} \\
\hline Pleiomorphic adenoma & $\begin{array}{l}\text { Lumican, perlecan, aggrecan, } \\
\text { C4S, C6S, DS, KS, HA }\end{array}$ & I, III, IV & $\begin{array}{l}\text { FGF2, Tenascin, FN, } \\
\text { ChM-I }\end{array}$ & {$[81-83]$} \\
\hline Vulvar squamous cell carcinoma & & & CD44, TGF-beta3 & {$[84]$} \\
\hline Mixed tumor of skin & & IV & Tenascin, FN & {$[85]$} \\
\hline Cholangiocarcinoma & Perlecan & & & {$[86]$} \\
\hline \multicolumn{5}{|c|}{ Miscellaneous tumors (nonsoft tissue, nonepithelial) } \\
\hline Myxopapillary ependymoma & HA, CS, HS & & & {$[87]$} \\
\hline Myxoid mesothelioma & HA & & & {$[88]$} \\
\hline Myxoid meningioma & $\mathrm{HA}, \mathrm{CS}$ & & & [89] \\
\hline
\end{tabular}

$K S$ keratin sulfate, $H A$ hyaluronic acid, $C 4 S$ chondroitin sulfate, $C 6 S$ chondroitin 6 sulfate, $D S$ dermatan sulfate, $H S$ heparan sulfate

\section{Proteoglycans}

PGs exhibit a wide variety of functions due to their structural diversity (Table 3 ). As PGs avidly bind proteins, they are involved in all cellular processes concerning cellmatrix, cell-cell, and ligand-receptor interactions. PGs are known to have affinity for a variety of ligands, including growth factors, cell adhesion molecules, ECM components, 
Table 3 GAGs and PGs: their role in physiology and pathologic processes [19]

\begin{tabular}{|c|c|c|}
\hline & Type and presence & Physiology \\
\hline C4S (CS-A) & $\begin{array}{l}\text { Sulfated galactosaminoglycan; } \\
\text { cartilage, skin and tendon }\end{array}$ & $\begin{array}{l}\text { Binds } \mathrm{Ca}^{2+}, \mathrm{Cu}^{2+} \text { and } \mathrm{Fe}^{2+} \text { ions; } \\
\text { antioxidant (better then } \mathrm{C} 6 \mathrm{~S} \text { and } \mathrm{HA} \text { ) }\end{array}$ \\
\hline C6S (CS-C) & $\begin{array}{l}\text { Sulfated galactosaminoglycan; } \\
\text { cartilage, brain secretory granules }\end{array}$ & $\begin{array}{l}\text { Reduces proinflammatory cytokines, } \\
\text { MMPs, NO, and apoptosis }\end{array}$ \\
\hline DS (CS-B) & $\begin{array}{l}\text { Sulfated galactosaminoglycan; skin, } \\
\text { blood vessels, heart, tendons, } \\
\text { lungs }\end{array}$ & $\begin{array}{l}\text { Regulation ECM integrity and cellular } \\
\text { signaling; DS selectively activates } \\
\text { heparin cofactor II that inactivates } \\
\text { thrombin; carcinogenesis, wound repair, } \\
\text { and fibrosis; DS binds water, coagulation }\end{array}$ \\
\hline HA & $\begin{array}{l}\text { Lack sulfation and epimerization } \\
\text { of glucuronic acid moiety to uronic } \\
\text { acid, the only GAG synthesized in } \\
\text { the cytoplasm at the plasma } \\
\text { membrane and also the only GAG } \\
\text { that is synthesized without core } \\
\text { protein. Connective, epithelial and } \\
\text { neural tissue. abundant in cartilage } \\
\text { and bone }\end{array}$ & $\begin{array}{l}\text { Early development, tissue organization, } \\
\text { cell proliferation, facilitate migration and } \\
\text { condensation of mesenchymal cells, } \\
\text { participates in joint cavity formation, } \\
\text { binds and immobilizes aggrecan, } \\
\text { regulates osteoblast and osteoclast } \\
\text { function. HA works as a scaffold for } \\
\text { building PGs, suppresses cartilage } \\
\text { degeneration and reduce pain perception, } \\
\text { associated with cell adhesion and } \\
\text { motility, suppresses prostaglandin E2 and } \\
\text { IL-1 production, activates SRC, FAK, } \\
\text { ERK and PKC whereas interaction with } \\
\text { CD44 also regulates ERBB, PI3K, regu } \\
\text { lates phosphorylation of BAD and hence } \\
\text { promotes cell survival, contributes to cell } \\
\text { proliferation and migration, bone turn } \\
\text { over, involved in tissue repair in skin, } \\
\text { binds to receptor CD44 }\end{array}$ \\
\hline
\end{tabular}

HS Sulfated glucosaminoglycan; all types of cells, highly abundant in ECM of the skeleton

Sulfated glucosaminoglycan; $\mathrm{N}$-glycan KSI or O-glycan KSII. Highly abundant in cornea and cartilage. Also found in epithelial tissue, central nervous system

Aggrecan O- and N-linked KSII, CS, DS, KS (HS absent), cartilage
Pathology

Decreased in OA, mediate adherence of plasmodium infected red blood cells

Laryngeal cancer, decreased in OA, increased in early atherosclerotic lesions

Dermatan sulfate accumulates abnormally in several of the mucopolysaccharidosis disorders and in myxomatous degeneration. Involved in cardiovascular disease, infection, fibrosis

Used for treatment of osteoarthritis

Sequesters chemokines or FGF towards migrating tumor cells, promotes metastasis, multiple osteochondromas (MO) - benign bone cartilaginous tumor caused by mutant in EXT1 or EXT2, accumulated in mucopolysaccharidoses separation of the niche from cellular and signaling influence of surrounding environment, involved in skeletal patterning, differentiation, growth and homeostasis, critical for hematopoietic stem cell inch, Ndst1 mutation causes brain/skull defects and lung surfactant problems resulting in perinatal lethality, Ndst 2 mutant have defective granule formation in mast cells, stimulates angiogenesis, osteocastogenesis, skeletal patterning, differentiation and homeostasis, coreceptor for morphogens, sequester growth factors and cytokines to regulate cell differentiation and growth, FGF-binding, binds fibronectin

Maintains proper special organization of the type I collagen fibrils and promotes transparency of cornea, cellular recognition of protein ligands, cell motility

Maintains tissue hydration, contributes to the mechanical properties of tissue, inhibits migration of neural crest cells, null mice show cartilage defects and delay in bone development
Corneal opacity and corneal dystrophy (KS lacks GlcNAc sulfation), epithelialderived carcinoma cells, alerted sulfation levels of KS was found in brain of Alzheimer patients

Chondrodystrophy, nanomelia, cartilage matrix deficiency (CMD), murine brachymorphism (bm), spondyloepimetaphyseal dysplasia enhanced expression in chondroblastoma, chondroma, chondrosarcoma, osteosarcoma, decreased in squamous cell carcinoma chondrodystrophy, nanomelia, 
Table 3 (continued)

\begin{tabular}{|c|c|c|c|}
\hline & Type and presence & Physiology & Pathology \\
\hline & & & $\begin{array}{l}\text { cartilage matrix deficiency, } \\
\text { spondyloepimataphyseal dysplasia }\end{array}$ \\
\hline Biglycan & $\begin{array}{l}\mathrm{CS}, \mathrm{DS} \text { (HS absent), bone, } \\
\text { cartilage, skin, connective } \\
\text { tissue }\end{array}$ & $\begin{array}{l}\text { Activates cell division, organization } \\
\text { of collage fibers, increased in vascular } \\
\text { injury, upregulates p } 27 \text { and downregulates } \\
\text { cyclin A and proliferating cell nuclear } \\
\text { antigen, maintaining proper number of } \\
\text { mature osteoblasts and survival of bone } \\
\text { marrow stromal cells, organization of } \\
\text { collagen fibers, regulator of cell cycle, } \\
\text { binds TGF-beta }\end{array}$ & $\begin{array}{l}\text { Overexpressed in pancreatic cancer } \\
\text { and hyperplasic thymus osteoporosis }\end{array}$ \\
\hline Decorin & $\begin{array}{l}\text { CS, DS (HS absent), } \\
\text { connective tissue, cornea }\end{array}$ & $\begin{array}{l}\text { Inhibits collagen fiber formation by } \\
\text { interaction with col I, col II, and col } \\
\text { VI, inhibits cell division, adhesion, } \\
\text { increased in vascular injury, downregulates } \\
\text { Erbb2 and MAP kinases, upregulates p } 21 \\
\text { CDK inhibitor leading to inhibition of cell } \\
\text { proliferation and specific induction of } \\
\text { apoptosis in transformed cells. maintaining } \\
\text { proper number of mature osteoblasts and } \\
\text { maintaining survival of bone marrow } \\
\text { stromal cells, bind nonfibril collagens } \\
\text { XII and XIV, regulates cell proliferation, } \\
\text { binds TGF-beta, mediates EGF signaling } \\
\text { by binding to EGFR }\end{array}$ & $\begin{array}{l}\text { Antiproliferative properties in tumor } \\
\text { growth, overexpressed in colorectal } \\
\text { carcinoma, colon adenocarcinoma, } \\
\text { melanoma, osteosarcoma, basal cell } \\
\text { carcinoma, } \\
\text { inhibits migration of MG-63 osteosarcoma } \\
\text { cells, reduced decorin levels were found } \\
\text { in lung adenocarcinoma, squamous } \\
\text { carcinoma, breast carcinoma, hepatocellular } \\
\text { carcinoma and ovarian tumors, may } \\
\text { regulate tumor angiogenesis, overexpression } \\
\text { is often associated with shift from DS to } \\
\text { CS, osteoporosis }\end{array}$ \\
\hline Lumican & $\mathrm{KS}$, cornea & $\begin{array}{l}\text { Upregulates p } 27 \text { and downregulates } \\
\text { cyclin A and proliferating cell nuclear } \\
\text { antigen, regulates collagen fibril } \\
\text { organization and circumferential growth, } \\
\text { corneal transparency, and epithelial cell } \\
\text { migration and tissue repair }\end{array}$ & $\begin{array}{l}\text { Upregulated in pancreatic, colorectal } \\
\text { and breast cancers, stroma of salivary } \\
\text { pleiotropic adenoma, reduced expression } \\
\text { is correlated with progression of breast } \\
\text { carcinoma }\end{array}$ \\
\hline Perlecan & $\begin{array}{l}\text { HS, CS, cartilage, limb bud } \\
\text { mesenchyme, articular } \\
\text { cartilage, bone marrow stroma, } \\
\text { all basal membranes, } \\
\text { vasculature }\end{array}$ & $\begin{array}{l}\text { Growth factor signaling, collagen } \\
\text { fibrillogenesis, structural stability, } \\
\text { vasculogenesis, endorepellin, } \\
\text { antiangiogenic factor, chondrocyte } \\
\text { proliferation and differentiation, } \\
\text { collagen I and II fibrillogenesis, } \\
\text { vasculogenesis, mediator of Shh } \\
\text { signaling, Wnt signaling, TGF-beta } \\
\text { signaling in the skeleton, regulates } \\
\text { FGF2 signaling }\end{array}$ & $\begin{array}{l}\text { Schwartz-Jampel syndrome, dyssegmental } \\
\text { dysplasia Silverman-Handmaker } \\
\text { type (DDSH), perlecan-null } \\
\text { embryo chondroplasia, } \\
\text { prostate tumor metastasis }\end{array}$ \\
\hline Versican & $\begin{array}{l}\mathrm{C} 6 \mathrm{~S}>\mathrm{C} 4 \mathrm{~S}>\mathrm{DS} \text { (HS, KS absent), } \\
\text { connective tissue, aorta, brain; } \\
\text { fibroblasts. important for vascular } \\
\text { biology }\end{array}$ & $\begin{array}{l}\text { Lipid retention, modification and } \\
\text { accumulation, hydration of ECM, } \\
\text { cell proliferation, migration, embryo } \\
\text { development, binds HA, CD44, and } \\
\text { chemokines }\end{array}$ & $\begin{array}{l}\text { Promotes tumor growth and spread, expressed } \\
\text { in the stroma of nearly all human cancers } \\
\text { (prostate, breast, lung, ovarian cancers } \\
\text { and odontogenic tumors, melanoma, brain } \\
\text { tumors, pharyngeal squamous cell } \\
\text { carcinoma, keratinocyte tumors, } \\
\text { atherosclerosis) }\end{array}$ \\
\hline
\end{tabular}

enzymes, and enzyme inhibitors [22]. Lecticans bind other ECM proteins with its C-type lectin motif, facilitating the formation of networks permissive for cell growth [23]. For example, aggrecan and versican associate tightly with both HA, thereby maintaining tissue hydration. Due to the EGFlike repeats, lecticans are directly involved in growth control. Versican stimulates the proliferation of fibroblasts and is highly expressed by fast-growing cells and present in myxoid areas of both reactive and neoplastic (mesenchymal and epithelial) lesions (Table 2) [24].

Small leucine-rich proteoglycans

SLRPs are structurally and functionally related ECM molecules and abundantly expressed in connective tissues. Decorin and biglycan bind to collagen and influence collagen fibrillo- 
genesis and ECM assembly in various ways: (a) due to its curved shape, decorin is able to bind to collagen types I, II, VI, and XIV linking them together and to fibronectin [25], (b) by decorating collagen fibers, decorin protects them from degradation by collagenases [25, 26], and (c) by its attached GAG chain, decorin is capable of modulating the activity of TGF-beta, which plays a central role in fibrogenesis $[13,25$, 27]. Biglycan- and decorin-deficient mice show irregular and defective collagen fibrils, fragile skin, and a phenotype that closely resembles that of patients with Ehlers-Danlos syndrome [28]. In wound healing, there is a spatial temporal regulation of the expression of the different SLRPs (decorin, lumican, fibromodulin, and biglycan) tightly controlling the transformation of the myxoid ECM of granulation tissue towards fibrotic scar formation [29]. Myxoid areas in pleomorphic adenoma of the salivary gland and odontogenic myxoma lack expression of biglycan, lumican, and decorin, whereas these SLRPs are diffusely present in the fibrotic parts of the ECM of these tumors (Table 2). This suggests that the absence of SLRPs might contribute to impaired ECM formation resulting in a mere myxoid morphology.

\section{Collagens}

As form follows function [30], different collagens have different properties. In the initial phase of wound healing, collagen type I is quickly produced by fibroblasts and replaced by collagen type III in the later stage of scar formation [29]. The FACIT collagen types XII and XIV do not form collagen fibrils themselves but associate with fibrillary collagens, such as collagen type I, decorin, and GAGs, linking them together [31-33]. Collagen type XIV interacts with dermatan sulfate sequences on the single chondroitin sulfate/dermatan sulfate chain attached to decorin, thereby providing a link between the fibril-forming and the fibril-associated collagens [32]. Collagen type XIV is expressed significantly higher in grade I myxofibrosarcoma than in intramuscular myxoma (including its cellular variant) [34]. On one hand, this might have implications for ECM assembly and tumor development, thereby playing a potential role in the different biology and clinical behavior of these different entities; on the other hand, the effect of cell-ECM interaction in these tumors might work the other way around, as collagen XIV induces differentiation of fibroblastic cells [35]. Higher expression of collagen XIV in myxofibrosarcoma is associated with a more mature morphology of the tumor cells compared to intramuscular myxoma [5].

\section{Other ECM molecules}

Fibronectin plays a role in various biological processes, such as wound healing, host defense, regulation of ECM assembly, adhesion, and proliferation [36]. It is also a key molecule in cell-ECM signaling, and aberrant activation of fibronectin-ECM signaling has been described in many tumors [37]. Likewise, tenascin C is an ECM glycoprotein of which the spatial and temporal expression is tightly regulated during fetal development [38]. It has been shown that the tenascin $\mathrm{C}$-encoding gene is upregulated in several pathologic conditions, such as wound healing, inflammation, and malignancies [38]. Elevated tenascin C expression has been found in epithelial and mesenchymal tumors, both in tumor and stromal cells, and is associated with unfavorable disease outcome (Table 2) [18]. Tenascin C attaches to cells via integrins, though the effect of this interaction on cellular signaling and tumor development is largely unknown [39].

\section{Putative relevance for routine pathology practice}

In routine general practice, one encounters a group of tumors, mesenchymal as well as epithelial, which may show variable degrees of myxoid appearance of their ECM. Myxoid tumors of soft tissue, the focus of this paper, encompass a heterogeneous group of lesions characterized by a marked abundance of extracellular mucoid/myxoid matrix (Table 1). This group of tumors exhibits a broad range of biological behavior varying from those which are entirely benign via locally aggressive (but nonmetastasizing) behavior to those which are frankly malignant; hence, accurate histopathological diagnosis is essential for appropriate clinical management. Till today, there have been no convincing data which demonstrate that the composition of the myxoid matrix significantly differ between tumors (both of mesenchymal and/or epithelial origin) and reactive lesions. From a biochemical point of view, the term "myxoid" is best considered a wastebasket of many different proteins and other (macro)molecules which might all have a different function (Tables 2 and 3). While determination of the different GAGs in myxoid tumors is interesting from a research point of view, Scott's critical electrolyte concentration (CEC) method is no longer a routinely used technique by pathologists. Most myxoid tumors of soft tissue tumors contain HA (Table 2), and consequently, its detection is no longer regarded as discriminatory in differential diagnoses. Outside the academic setting (where recourse to sophisticated biochemical and molecular genetics techniques is generally not possible), when confronted with challenging myxoid lesions, the diagnostic process relies primarily on careful and discriminatory histopathological evaluation in order to reach a correct diagnosis. Routine histological criteria (e.g., tumor demarcation, growth and vascular pattern, and nuclear atypia) remain the hallmarks of diagnosis. (Immuno-) histochemistry may be useful as a adjunct in the setting of 
certain differential diagnostic considerations, but is often not discriminatory and, therefore, not diagnostically useful [8]. Molecular cytogenetics is of increasing importance for diagnosis in difficult cases, as the genetic makeup of an increasing number of myxoid tumors of soft tissue is being elucidated (Table 1). Next to genetic causes (such as driver mutations, translocations, or gene amplifications), environmental factors have been shown to play an important role in tumorigenesis of both epithelial and mesenchymal tumors [40]. Virchow already mentioned the possible relationship between the histological appearance of the myxoid ECM of tumors and their differences in biological behavior [1]. It is very tempting to believe that GAGs and PGs play an important role in the biology of myxoid lesions rather than just being a byproduct of (myo)fibroblastic differentiation. Intramuscular myxoma expresses significantly less decorin and collagen VI and XIV (both protein and mRNA level) than grade I myxofibrosarcoma [34]. Next to decorin, liquid chromatography-mass spectrometry revealed other SLRPs (i.e., lumican, prolargin 4, biglycan) present in tumor lysates of grade I myxofibrosarcoma but not of intramuscular myxoma [34]. This suggest that ECM formation in intramuscular myxoma is impaired compared to grade I myxofibrosarcoma. Increased ECM rigidity activates integrins and subsequently leads to stimulation of the rho/Rock pathway and cell migration and invasion [41]. In this respect, the morphological similarity between the process of wound healing and myxoid changes/areas in (non)neoplastic lesions is rather striking. In the early phase, granulation tissue shows a loose, edematous/myxoid ECM rich in GAGs. In the subsequent phase, there is structural organization of the ECM with deposition of collagens produced by myofibroblasts which locally (de)differentiate from fibroblast/smooth muscle cells or are derived from the bone marrow. The term "myxoid" might not only be synonymous with (aberrant turnover and) the presence of GAGs, but also reflects the absence of proper ECM assembly or incomplete ECM formation. This might well explain that a myxoid morphology of the ECM is not specific at all and can be seen in reactive/non-neoplastic processes as well as in benign and malignant tumors (Fig. 3). As already extensively discussed in this paper, the ECM is dependent on the interplay of various macromolecules (polysaccharides and proteins) which determine its texture and consistency. It is becoming increasingly clear that, within this group of lesions, various tumor types may show differences in the biological composition of their myxoid matrix, as determined by differences in the relative proportions of the constituent macromolecules and the presence or absence of specific stromal constituents. Clearly, this is an important and highly relevant area for further research in order to identify tumor-specific markers and to consequently develop economically viable and user- friendly detection methods to facilitate the diagnostic process and ensure increasingly accurate histopathologic diagnosis.

Acknowledgements Stefan M. Willems was financially supported by a grant from The Netherlands Organization for Health Research and Development (project no. 920-03-403).

Conflict of interest statement We declare that we have no conflict of interest.

Open Access This article is distributed under the terms of the Creative Commons Attribution Noncommercial License which permits any noncommercial use, distribution, and reproduction in any medium, provided the original author(s) and source are credited.

\section{References}

1. Virchow R (1858) Die cellularpathologie in ihrer Begrundung auf physiologische und pathologische Gewebelehre. Hirschwald, Berlin

2. Dunglison R (1865) Medical lexicon. A dictionary of medical science. Blanchard and Lea, Philadelphia

3. Muller J (1838) Uber den feineren bau und die formen der krankhaften geschwulste. Haberling, Berlin

4. Bryant T (1802) Tumors and tumor formation. Churchill, New York.

5. Stout AP (1948) Myxoma, the tumor of primitive mesenchyme. Ann Surg 127:706-719

6. Sponsel KH, McDonald JR, Ghormley RK (1952) Myxoma and myxosarcoma of the soft tissues of the extremities. J Bone Joint Surg Am 34(A):820-826

7. Fletcher CDM, Unni KK, Mertens F (2002) WHO classification of tumours. Pathology and genetics of tumours of soft tissue and bone. IARC, Lyon

8. Graadt van Roggen JF, Hogendoorn PCW, Fletcher CDM (1999) Myxoid tumours of soft tissue. Histopathology 35:291-312

9. Steedman HF (1950) Alcian Blue 8 GS: a new stain for mucin. Q J Microsc Sci 3:477-479

10. Scott JE, Dorling J (1965) Differential staining of acid glycosaminoglycans (mucopolysaccharides) by alcian blue in salt solutions. Histochemie 5:221-233

11. Kindblom LG, Angervall L (1975) Histochemical characterization of mucosubstances in bone and soft tissue-tumors. Cancer 36:985-994

12. Gandhi NS, Mancera RL (2008) The structure of glycosaminoglycans and their interactions with proteins. Chem Biol Drug Des $72: 455-482$

13. Kresse H, Schonherr E (2001) Proteoglycans of the extracellular matrix and growth control. J Cell Physiol 189:266-274

14. Schaefer L, Iozzo RV (2008) Biological functions of the small leucine-rich proteoglycans: from genetics to signal transduction. J Biol Chem 283:21305-21309

15. Kadler KE, Hill A, Canty-Laird EG (2008) Collagen fibrillogenesis: fibronectin, integrins, and minor collagens as organizers and nucleators. Curr Opin Cell Biol 20:495-501

16. White ES, Baralle FE, Muro AF (2008) New insights into form and function of fibronectin splice variants. J Pathol 216:1-14

17. Bosman FT, Stamenkovic I (2003) Functional structure and composition of the extracellular matrix. J Pathol 200:423-428 
18. Orend G, Chiquet-Ehrismann R (2006) Tenascin-C induced signaling in cancer. Cancer Lett 244:143-163

19. Lamoureux F, Baud'huin M, Duplomb L et al (2007) Proteoglycans: key partners in bone cell biology. BioEssays 29:758-771

20. Willems SM, Schrage YM, Baelde JJ et al (2008) Myxoid tumours of soft tissue: the so-called myxoid extracellular matrix is heterogeneous in composition. Histopathology 52:465-474

21. Almond A (2007) Hyaluronan. Cell Mol Life Sci 64:1591-1596

22. Rodgers KD, San Antonio JD, Jacenko O (2008) Heparan sulfate proteoglycans: a GAGgle of skeletal-hematopoietic regulators. Dev Dyn 237:2622-2642

23. Evanko SP, Angello JC, Wight TN (1999) Formation of hyaluronan- and versican-rich pericellular matrix is required for proliferation and migration of vascular smooth muscle cells. Arterioscler Thromb Vasc Biol 19:1004-1013

24. Zimmermann DR, Dours-Zimmermann MT, Schubert $M$ et al (1994) Versican is expressed in the proliferating zone in the epidermis and in association with the elastic network of the dermis. J Cell Biol 124:817-825

25. McEwan PA, Scott PG, Bishop PN et al (2006) Structural correlations in the family of small leucine-rich repeat proteins and proteoglycans. J Struct Biol 155:294-305

26. Geng Y, McQuillan D, Roughley PJ (2006) SLRP interaction can protect collagen fibrils from cleavage by collagenases. Matrix Biol 25:484-491

27. Ferdous Z, Wei VM, Iozzo R et al (2007) Decorin-transforming growth factor- interaction regulates matrix organization and mechanical characteristics of three-dimensional collagen matrices. J Biol Chem 282:35887-35898

28. Danielson KG, Baribault H, Holmes DF et al (1997) Targeted disruption of decorin leads to abnormal collagen fibril morphology and skin fragility. J Cell Biol 136:729-743

29. Martinez DA, Vailas AC, Vanderby R et al (2007) Temporal extracellular matrix adaptations in ligament during wound healing and hindlimb unloading. Am J Physiol Regul Integr Comp Physiol 293:R1552-R1560

30. Sullivan LH (1896) The tall office building artistically considered. Lippincott's Magazine 57:403-409

31. Ehnis T, Dieterich W, Bauer M et al (1997) Localization of a binding site for the proteoglycan decorin on collagen XIV (undulin). J Biol Chem 272:20414-20419

32. Ehnis T, Dieterich W, Bauer M et al (1996) A chondroitin/ dermatan sulfate form of CD44 is a receptor for collagen XIV (undulin). Exp Cell Res 229:388-397

33. Canty EG, Kadler KE (2005) Procollagen trafficking, processing and fibrillogenesis. J Cell Sci 118:1341-1353

34. Willems SM, Mohseny AB, Balog C et al (2009) Cellular/ intramuscular myxoma and grade I myxofibrosarcoma are characterized by distinct genetic alterations and specific composition of their extracellular matrix. J Cell Mol Med 7:12911301

35. Ruehl M, Erben U, Schuppan D et al (2005) The elongated first fibronectin type III domain of collagen XIV is an inducer of quiescence and differentiation in fibroblasts and preadipocytes. $\mathrm{J}$ Biol Chem 280:38537-38543

36. Vakonakis I, Campbell ID (2007) Extracellular matrix: from atomic resolution to ultrastructure. Curr Opin Cell Biol 19:578-583

37. Larsen M, Artym VV, Green JA et al (2006) The matrix reorganized: extracellular matrix remodeling and integrin signaling. Curr Opin Cell Biol 18:463-471

38. Harty M, Neff AW, King MW et al (2003) Regeneration or scarring: an immunologic perspective. Dev Dyn 226:268-279

39. Jones FS, Jones PL (2000) The tenascin family of ECM glycoproteins: structure, function, and regulation during embryonic development and tissue remodeling. Dev Dyn 218:235-259
40. De Wever O, Mareel M (2003) Role of tissue stroma in cancer cell invasion. J Pathol 200:429-447

41. Berrier AL, Yamada KM (2007) Cell-matrix adhesion. J Cell Physiol 213:565-573

42. Fletcher CDM (1990) Benign fibrous histiocytoma of subcutaneous and deep soft tissue: a clinicopathologic analysis of 21 cases. Am J Surg Pathol 14:801-809

43. Carney JA, Gordon H, Carpenter PC et al (1985) The complex of myxomas, spotty pigmentation, and endocrine overactivity. Medicine (Baltimore) 64:270-283

44. Meng GZ, Zhang HY, Zhang Z et al (2009) Myofibroblastic sarcoma vs nodular fasciitis: a comparative study of chromosomal imbalances. Am J Clin Pathol 131:701-709

45. Perdigao PF, Stergiopoulos SG, De Marco L et al (2005) Molecular and immunohistochemical investigation of protein kinase a regulatory subunit type $1 \mathrm{~A}$ (PRKAR1A) in odontogenic myxomas. Genes Chromosomes Cancer 44:204-211

46. Hallor KH, Sciot R, Staaf J et al (2009) Two genetic pathways, $\mathrm{t}(1 ; 10)$ and amplification of $3 \mathrm{p} 11-12$, in myxoinflammatory fibroblastic sarcoma, haemosiderotic fibrolipomatous tumour, and morphologically similar lesions. J Pathol 217:716-727

47. Calonje E, Mentzel T, Fletcher CDM (1994) Cellular benign fibrous histiocytoma. Clinicopathologic analysis of 74 cases of a distinctive variant of cutaneous fibrous histiocytoma with frequent recurrence. Am J Surg Pathol 18:668-676

48. Willems SM, Debiec-Rychter M, Szuhai K et al (2006) Local recurrence of myxofibrosarcoma is associated with increase in tumour grade and cytogenetic aberrations, suggesting a multistep tumour progression model. Mod Pathol 19:407-416

49. Enzinger FM, Shiraki M (1972) Extraskeletal myxoid chondrosarcoma. An analysis of 34 cases. Hum Pathol 3:421-435

50. Evans HL (1993) Low-grade fibromyxoid sarcoma. A report of 12 cases. Am J Surg Pathol 17:595-600

51. Turc-Carel C, Limon J, Dal CP et al (1986) Cytogenetic studies of adipose tissue tumors. II. Recurrent reciprocal translocation $\mathrm{t}(12 ; 16)(\mathrm{q} 13 ; \mathrm{p} 11)$ in myxoid liposarcomas. Cancer Genet Cytogenet 23:291-299

52. Rubin BP, Fletcher CDM (2000) Myxoid leiomyosarcoma of soft tissue, an underrecognized variant. Am J Surg Pathol 24:927-936

53. Brems H, Beert E, De Ravel RT et al (2009) Mechanisms in the pathogenesis of malignant tumours in neurofibromatosis type 1 . Lancet Oncol 10:508-515

54. Pedeutour F, Simon MP, Minoletti F et al (1996) Translocation, $\mathrm{t}(17 ; 22)(\mathrm{q} 22 ; \mathrm{q} 13)$, in dermatofibrosarcoma protuberans: a new tumor-associated chromosome rearrangement. Cytogenet Cell Genet 72:171-174

55. Kaya G, Augsburger E, Chavaz P et al (2006) CD44 and hyaluronate expression in follicular mucinosis. J Cutan Pathol 33:227-230

56. Alves MF, Filgueira AL, Lorena DE et al (1998) Type I and type III collagens in cutaneous mucinosis. Am J Dermatopathol 20:41-47

57. Lengyel J, Vertes B (1956) Hyaluronic acid studies of local myxedema and of the stroma of skin cancer. Dermatologica 113:219-225

58. Chung IM, Gold HK, Schwartz SM et al (2002) Enhanced extracellular matrix accumulation in restenosis of coronary arteries after stent deployment. J Am Coll Cardiol 40:2072-2081

59. Wight TN (2002) Versican: a versatile extracellular matrix proteoglycan in cell biology. Curr Opin Cell Biol 14:617-623

60. Burke AP, Jarvelainen H, Kolodgie FD et al (2004) Superficial pseudoaneurysms: clinicopathologic aspects and involvement of extracellular matrix proteoglycans. Mod Pathol 17:482-488

61. Black A, French AT, Dukes-McEwan J et al (2005) Ultrastructural morphologic evaluation of the phenotype of valvular interstitial cells in dogs with myxomatous degeneration of the mitral valve. Am J Vet Res 66:1408-1414 
62. Nasuti JF, Zhang PJ, Feldman MD et al (2004) Fibrillin and other matrix proteins in mitral valve prolapse syndrome. Ann Thorac Surg 77:532-536

63. Aigner T, Oliveira AM, Nascimento AG (2004) Extraskeletal myxoid chondrosarcomas do not show a chondrocytic phenotype. Mod Pathol 17:214-221

64. Zhao M, Lu Y, Takata T, Mock D, Nikia H et al (1999) Immunohistochemical and histochemical characterization of the mucosubstances of odontogenic myxoma: histogenesis and differential diagnosis. Pathol Res Pract 195:391-397

65. Zamecnik M, Michal M (2000) Low-grade fibromyxoid sarcoma: a report of eight cases with histologic, immunohistochemical, and ultrastructural study. Ann Diagn Pathol 4:207-217

66. Gallager RL, Helwig EB (1980) Neurothekeoma-a benign cutaneous tumor of neural origin. Am J Clin Pathol 74:759-764

67. Hajdu SI (1979) Pathology of soft tissue Tumors. Lea and Febiger, Philadelphia

68. Fukuda T, Tsuneyoshi M (2000) Adhesion proteins, cellular morphology and fibrous components around the cell/extracellular-matrix interface in myxoid liposarcomas. J Cancer Res Clin Oncol 126:320-324

69. Mackenzie DH (1981) The myxoid tumors of somatic soft tissues. Am J Surg Pathol 5:443-458

70. Soder S, Inwards C, Muller S et al (2001) Cell biology and matrix biochemistry of chondromyxoid fibroma. Am J Clin Pathol 116:271-277

71. Calikoglu E, Chavaz P, Saurat JH et al (2003) Decreased CD44 expression and stromal hyaluronate accumulation in myxoid dermatofibroma. Dermatology 207:104-106

72. Yasui W, Oda N, Ito $\mathrm{H}$ et al (1991) Myxoid leiomyosarcoma of the stomach: a case report. Jpn J Clin Oncol 21:447-452

73. Lam RM, Hawkins ET, Roszka J (1984) Cardiac myxoma: histochemical and ultrastructural localization of glycosaminoglycans and proteoglycans. Ultrastruct Pathol 6:69-81

74. Folpe AL, Weiss SW (2003) Ossifying fibromyxoid tumor of soft parts: a clinicopathologic study of 70 cases with emphasis on atypical and malignant variants. Am J Surg Pathol 27:421-431

75. Yang P, Hirose T, Hasegawa T et al (1994) Ossifying fibromyxoid tumor of soft parts: a morphological and immunohistochemical study. Pathol Int 44:448-453

76. Hassanein AM, Atkinson SP, Al-Quran SZ et al (2008) Acral myxoinflammatory fibroblastic sarcomas: are they all low-grade neoplasms? J Cutan Pathol 35:186-191

77. Johnson WC, Graham JH, Helwig EB (1965) Cutaneous myxoid cyst. A clinicopathological and histochemical study. JAMA 191:15-20

78. Begin LR, Clement PB, Kirk ME et al (1985) Aggressive angiomyxoma of pelvic soft parts: a clinicopathologic study of nine cases. Hum Pathol 16:621-628

79. Calikoglu E, Augsburger E, Masouye I et al (2002) Hyaluronate accumulation and decreased CD44 expression in perifollicular solitary cutaneous myxoma. Dermatology 205:122-126
80. Kusafuka K, Muramatsu K, Kasami M et al (2008) Cartilaginous features in matrix-producing carcinoma of the breast: four cases report with histochemical and immunohistochemical analysis of matrix molecules. Mod Pathol 21:1282-1292

81. Kusafuka K, Ishiwata T, Sugisaki Y et al (2004) Lumican expression is associated with the formation of mesenchyme-like elements in salivary pleomorphic adenomas. J Pathol 203:953960

82. Nara Y, Takeuchi J, Yoshida K et al (1991) Immunohistochemical characterisation of extracellular matrix components of salivary gland tumours. Br J Cancer 64:307-314

83. Kusafuka K, Hiraki Y, Shukunami C et al (2001) Cartilagespecific matrix protein chondromodulin-I is associated with chondroid formation in salivary pleomorphic adenomas: immunohistochemical analysis. Am J Pathol 158:1465-1472

84. Ambros RA, Kallakury BV, Malfetano JH et al (1996) Cytokine, cell adhesion receptor, and tumor suppressor gene expression in vulvar squamous carcinoma: correlation with prominent fibromyxoid stromal response. Int J Gynecol Pathol $15: 320-325$

85. Franchi A, Dini M, Paglierani M et al (1995) Immunolocalization of extracellular matrix components in mixed tumors of the skin. Am J Dermatopathol 17:36-41

86. Sabit H, Tsuneyama K, Shimonishi T et al (2001) Enhanced expression of basement-membrane-type heparan sulfate proteoglycan in tumor fibro-myxoid stroma of intrahepatic cholangiocarcinoma. Pathol Int 51:248-256

87. Giordana MT, Bertolotto A, Mauro A et al (1982) Glycosaminoglycans in human cerebral tumors. Part II. Histochemical findings and correlations. Acta Neuropathol 57:299-305

88. Shia J, Qin J, Erlandson RA et al (2005) Malignant mesothelioma with a pronounced myxoid stroma: a clinical and pathological evaluation of 19 cases. Virchows Arch 447:828-834

89. Harrison JD, Rose PE (1985) Myxoid meningioma: histochemistry and electron microscopy. Acta Neuropathol 68:80-82

90. Henschen F (1926) Fall von ostitis Fibrosa mit multiplen Tumoren in deer umgebenden Muskulatur. Verh Dtsch Ges Pathol 21:93-97

91. Mazabraud A, Semat P, Roze R (1967) A propos de l'association de fibromyxomes des tissus mous à la dysplasie fibreuse des os. Presse Med 75:2223-2228

92. Weiss SW, Enzinger FM (1977) Myxoid variant of malignant fibrous histiocytoma. Cancer 39:1672-1685

93. Angervall L, Kindblom LG, Merck C (1977) Myxofibrosarcoma. A study of 30 cases. Acta Pathol Microbiol Scand A 85A:127140

94. Orndal C, Mandahl N, Rydholm A et al (1990) Chromosomal evolution and tumor progression in a myxoid liposarcoma. Acta Orthop Scand 61:99-105

95. Mentzel T, Calonje E, Wadden C et al (1996) Myxofibrosarcoma. Clinicopathologic analysis of 75 cases with emphasis on the lowgrade variant. Am J Surg Pathol 20:391-405 